\title{
CORROSION STUDY FOR WASTE TANKS EXPOSED TO HIGH TEMPERATURE AND SALT CONCENTRATION CONDITIONS (U)
}

\author{
By
}

\author{
John I. Mickalonis
}

\section{DISCLAIMER}

March, 1995

This report was prepared as an account of work sponsored by an agency of the United States Government. Neither the United States Government nor any agency thereof, nor any of their employees, makes any warranty, express or implied, or assumes any legal liability or responsibility for the accuracy, completeness, or usefulness of any information, apparatus, product, or process disclosed, or represents that its use would not infringe privately owned rights. Reference herein to any specific commercial product, process, or service by trade name, trademark, manufacturer, or otherwise does not necessarily constitute or imply its endorsement, recommendation, or favoring by the United States Government or any agency thereof. The views and opinions of authors expressed herein do not necessarily state or reflect those of the United States Government or any agency thereof. 


\section{DISCLAIMER}

This report was prepared as an account of work sponsored by an agency of the United States Government. Neither the United States Government nor any agency thereof, nor any of their employees, makes any warranty, express or implied, or assumes any legal liability or responsibility for the accuracy, completeness, or usefulness of any information, apparatus, product, or process disclosed, or represents that its use would not infringe privately owned rights. Reference herein to any specific commercial product, process, or service by trade name, trademark, manufacturer, or otherwise does not necessarily constitute or imply its endorsement, recommendation, or favoring by the United States Government or any agency thereof. The views and opinions of authors expressed herein do not necessarily state or reflect those of the United States Government or any agency thereof. 


\section{DISCLAIMER}

Portions of this document may be illegible in electronic image products. Images are produced from the best available original document. 
Retention: 20 years

\title{
CORROSION STUDY FOR WASTE TANKS EXPOSED TO HIGH
} TEMPERATURE AND SALT CONCENTRATION CONDITIONS (U)

\author{
by
}

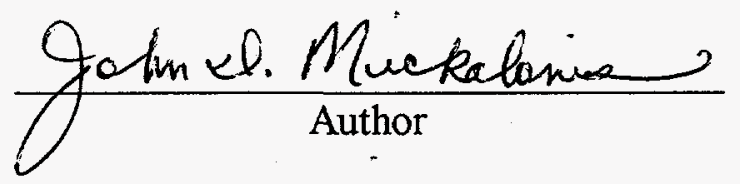

ISSUED: MARCH, 1995
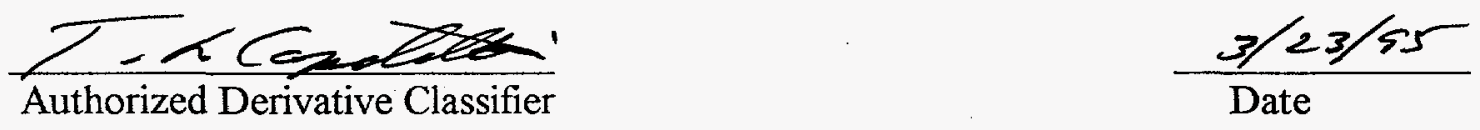

SRTC Savannah River Technology Center, Aiken, SC, 29808

Westinghouse Savannah River Company

Prepared for the U. S. Department of Energy under Contract DE-AC09-89SR18035 
DOCUMENT: WSRC-TR-95-0116

TITLE: CORROSION STUDY FOR WASTE TANKS EXPOSED TO HIGH TEMPERATURE AND SALT CONCENTRATION CONDITIONS (U)

APPROVALS

P. E. Tap, Technical Reviewer

SRTC/ASET/Materials Technology Section

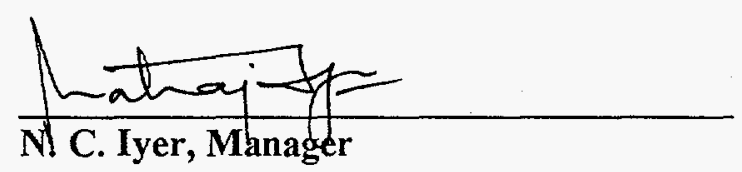

Materials Application and Corrosion Technology SRTC/ASET/Materials Technology Section
DATE: $3-22-55$

DATE: $\quad 3-22-95$

DATE: $3 / 23 / 55$

T. L. Capeletti, Manager

Materials Technology Section 
TABLE OF CONTENTS

$\begin{array}{lc}\text { SUMMARY } & 1 \\ \text { INTRODUCTION } & 1 \\ \text { EXPERIMENTAL PROCEDURE } & 1 \\ \text { RESULTS AND DISCUSSION } & 2 \\ \text { CONCLUSIONS } & 4 \\ \text { REFERENCES } & 4 \\ \text { TABLES } & 5 \\ \text { FIGURES } & 8\end{array}$

1 


\section{Corrsion Study For Waste Tanks Exposed To High Temperature And Salt Concentration Conditions (U)}

\section{Summary}

During salt dissolution, waste compositions may reach temperature and nitrate concentrations not covered by the present technical standards. Stress corrosion cracking (SCC) is a possible degradation mechanism of waste tank steels. Accelerated electrochemical tests were performed to identify potential ranges where SCC could occur for ASTM A537 and A285 plain carbon steels. The results showed that the only probable potential range for SCC would be that for the normal oxide state $(-0.200$ to $-0.400 \mathrm{~V})$. Possible oxide instability was also identified for the range of 0.000 to $0.200 \mathrm{~V}$. These ranges will be used for the planned slow strain rate test to determine SCC susceptibility.

\section{Introduction}

Potentiodynamic polarization test were performed to determine electrochemical potential ranges where plain carbon steels could be susceptible to stress corrosion cracking (SCC). These tests are part of the task related to TTR-HLE-94090, entitled "Temperature Effects During Salt Dissolution" [1]. The primary objective of this task is to determine the corrosion inhibitor and temperature requirements during salt dissolution [2]. High temperatures $\left(>70^{\circ} \mathrm{C}\right)$ and high nitrate concentrations $(>8.0 \mathrm{M})$, which have occurred during dissolution, may cause SCC of the waste tank. SCC is known to occur within certain potential ranges, which change with the material of construction and waste composition [3]. Potentiodynamic polarization testing was used to determine possible potential ranges which would be used in the slow strain rate test (SSRT) matrix.

\section{Experimental Procedure}

Potentiodynamic polarization testing (PPT) consists of applying a sequentially changing potential to a sample that is exposed to the solution of interest. The responding current is measured to establish a current-potential releationship. The data, which are normally displayed as potential-log current graphs, are analyzed to determine the probable corrosion mechanisms. Various relationships are characteristic of certain corrosion mechanisms. SCC has been found to be prevalent at potentials where the responding current has a large change. This change was associated with a transformation in the passivity of the material.

The PPT was performed with disc-shaped samples of both ASTM Types A285 and A537 plain carbon steels, which are the materials of construction for Type II and some Type III waste tanks, respectively. The tests were limited to these alloys since ASTM Types A516 and A106 plain carbon steels have chemistries that are similar to A537 and A285. A516 and $\mathrm{A} 285$ are the materials of construction for some Type III waste tanks and the cooling 
coils. The test samples were obtained from Metals Sample (Munsford, AL) and their compositions are given in Table 1 . The surface was prepared with a 600 -grit finish just prior to a test. The surface area that was exposed to the test solution was $1 \mathrm{~cm}^{2}$.

Test solutions were simulated waste compositions in which the sodium nitrate, hydroxide, and nitite concentrations were varied. The compositions were chosen based on previous salt dissolutions and the maximum nitrate concentration that could be experimentally obtained [4]. Solutions at high and low values for both the nitrate concentration and temperature were tested to determine a range of results. The compositions and test temperatures for the solutions are given in Table 2. Fixed concentrations of other salts were also added to all the solutions. These additional components were: $0.1 \mathrm{M}$ sodium carbonate, $0.1 \mathrm{M}$ sodium sulfate, $0.05 \mathrm{M}$ sodium chloride, $0.05 \mathrm{M}$ sodium hypophosphate, and $0.005 \mathrm{M}$ sodium chromate.

A schematic diagram of the test cell is shown in Figure 1. The cell, which was a standard electrochemical cell, consisted of a Pyrex glass container with graphite counter electrodes and a $\mathrm{Ag} / \mathrm{AgCl}$ reference electrode. A temperature controller was used with a thermometer to maintain a temperature of either 75 or $95^{\circ} \mathrm{C}$. The solutions were not stirred or purged with a gas. The test samples were placed in the solution and allowed to reach an equilibrium steady state potential prior to starting the test.

The test procedure was similar to that given in ASTM G5-87, "Standard Reference Test Method for Making Potentiostatic and Potentiodynamic Anodic Polarization Measurements" [5]. After a sample stabilized in the solution, a potential of $-0.800 \mathrm{~V}$ versus the open-circuit potential was applied and held for five minutes. This polarization reduces surface oxides on the sample. Following this step, the sample potential was ramped to $0.800 \mathrm{~V}$ at a scan rate of $16.7 \mathrm{mV} / \mathrm{sec}$ (fast scan). The sample was allowed to stabilize after this test for 30 minutes. The procedure was repeated on the same sample, except the scanning rate was changed to $0.33 \mathrm{mV} / \mathrm{sec}$ (slow scan). Duplicate tests were run for each solution.

\section{Results And Discussion}

The data analysis entailed identifying the potentials at which the measured currents for the fast and slow scan had a ratio greater than a thousand. The technique is based on the hypothesis that SCC occurs by crack tip dissolution [6]. The dissolution reactions at the crack tip occur at a faster rate than those either along the crack sides or at the outer surface. These surfaces have a passive oxide layer which slows any dissolution reactions. The crack sides must go through an active to passive transition since at one stage the side locations were at the tip. This PPT technique identifies the potentials at which this active to passive transition occurs.

The potential and current data displayed three relationships. These relationships, which were similar, are shown in Figure 2 on a potential-log current density graph. Scans A, B, and $\mathrm{C}$ were obtained from three different solutions at the fast scan rate. The scans for the 
slow rate are not shown for clarity. The arrows on the curves indicate the direction of scan. The first relationship as shown by Scan A had a current that steadily increased with the potential, indicating active dissolution or general corrosion. The amount of current that passes through the sample is related to the overall corrosion rate.

Scan B shows a small peak in the current which occurred at a specific potential, referred to as the peak potential. The peak potential for Scan B occurred at $0.050 \mathrm{~V}$. A change in the surface characteristics was a probable cause. The third relationship as shown by Scan $\mathrm{C}$ also had a current increase at a specific potential, referred to as the step potential. The step potential for scan $\mathrm{C}$ occurred at $0.100 \mathrm{~V}$. The average peak and step potentials are given in Table 3 . The difference between the second and third relationship may be attributable to the surface oxide. Samples as characterized by Scan $C$ could have a stable oxide so that the current prior to the step was constant with potential. A less stable or penetrable oxide would have increasing currents with potential as shown by Scan B. A larger current change, therefore, would occur at a transition potential for a stable oxide.

The potential-current relationships had a dependence on the nitrate and inhibitor concentrations. The results in Scans A and B were generally observed for the low nitrate solutions (5.5 and $8.0 \mathrm{M})$. The high nitrate solutions $(8.7$ and $9.7 \mathrm{M})$ more typically had results like Scans A and C. Solution A1, which had low inhibitor and nitrate concentrations, had results similar to the higher nitrate solutions. The more aggressive solutions with low inhibitor or high nitrate concentrations; therefore, tended to show more instability in the oxide. This instability may be an indicator of SCC susceptiblility.

The results were also affected by the scan rate. The slow scans, which were not shown in Figure 2, were shifted to lower current densities than those measured for the fast scans. These lower current densities showed that the extended time needed to petform the scan allowed a more stable surface oxide to form on the sample. As explained above, the results from the slower scan apply to the corrosion processes along the crack sides and the outer surface; those from the fast scan apply to the crack tip.

The potentials that were determined from these results included the steady state potential prior to performing the test (Ess), the corrosion potential (Ecorr), the transition potential, and the specific potential. Table 3 shows the average values for each material and scan rate in the tested solutions. Ecorr is the potential during a scan when the net current changes from cathodic to anodic. Ess and Ecorr should be similar if the polarization does not affect the sample. A large difference $(>0.100 \mathrm{~V})$ was observed for the fast scan in these tests since the samples were polarized to $-0.800 \mathrm{~V}$ to remove the surface oxide.

The transition potential was chosen as that in which the current density ratio between the fast and slow scan was greater than 1000 . The only potentials at which this ratio occurred was at Ecorr for the slow scan. These Ecorr values were similar to the Ess values and were in the range of -0.200 to $-0.400 \mathrm{~V}$. The specific potential, the peak and step potential discussed above, was where the oxide appeared to become less stable. These potentials fell in the range of 0.000 to $0.200 \mathrm{~V}$. The current density ratios at these potentials, however, 
were on the order of 10 , which was not indicative of SCC susceptibility. The ranges for both the transition and specific potentials fell within the range noted for nitrate SCC $(-0.300$ to $0.800 \mathrm{~V})[3]$.

The use of applied potentials during the Slow Strain Rate Test (SSRT), therefore, does not appear necessary. The similarity of the transition potentials to the potentials prior to testing showed that the normal state of the oxide on these steels is the most susceptible for SCC. However, since the specific potentials indicated some oxide instability several SSRT will be run under applied potential conditions. These steps would confirm the lack of SCC susceptibility at these potentials.

Pitting corrosion, which is generally associated with low nitrate waste compositions, was not found to occur in these tests. Pitting will be monitored during the wedge-opening loaded test that are planned to confirm this finding. These tests are long-term coupon tests and will be initiated after the SSRT.

\section{Conclusions}

PPT was conducted to identify probable potential ranges for SCC susceptibility for A537 and A285 plain carbon steels during salt dissolution. Waste compositions could attain nitrate and temperature conditions that are not covered by the present technical standards. The results showed that the range of -0.200 to $-0.400 \mathrm{~V}$ would be the most probable one for SCC, although the range of 0.000 to $0.200 \mathrm{~V}$ indicated some oxide instability. The solutions with a higher nitrate or lower inhibitor concentration were more aggressive. The slow strain rate tests, which are better indicators of SCC susceptibility, will be performed within these ranges.

\section{References}

1. Technical Task Request, HLE-TTR-94090, May 13, 1994.

2. J. I. Mickalonis, "Technical Task and Quality Assurance Plan for Temperature Effects During Salt Dissolution," SRT-MTS-94-2042, October, 1994.

3. R. S. Ondrejcin et al, Nuclear Technology, Vol. 44 (7), p 297, 1979.

4. J. I. Mickalonis, "Maximum Solubilities of Sodium Nitrate In Simulated Waste (U), SRT-MTS-94-2043, October 31, 1994.

5. ASTM G5-87, Standard Reference Test Method for Making Potentiostatic and Potentiodynamic Anodic Polarization Measurements, American Society for Testing and Materials, Philadelphia, PA, 1987.

6. R. N. Parkins and N. J. H. Holyrod, Corrosion, Vol. 38 (5), p 245, 1982. 
Table 1. Chemical Composition Of Carbon Steel Test Samples

\begin{tabular}{|c|c|c|c|c|c|}
\hline \multirow[b]{2}{*}{ Type Steel } & \multicolumn{5}{|c|}{ Chemical Analysis (\%) } \\
\hline & $\mathrm{C}$ & $\mathrm{Mn}$ & $\mathrm{P}$ & $\mathrm{S}$ & $\mathrm{Si}$ \\
\hline A285 & $0.28 \max$ & $0.90 \max$ & $0.035 \max$ & $0.045 \max$ & -- \\
\hline A537 & $0.24 \max$ & $0.70-1.60$ & $0.035 \max$ & $0.040 \max$ & $0.15-0.50$ \\
\hline
\end{tabular}


Table 2. Simulated Waste Compositions 1

\begin{tabular}{|c|c|c|c|}
\hline Solution Name & Component & Concentration (M) & Temperature $\left({ }^{\circ} \mathrm{C}\right)$ \\
\hline \multirow[t]{3}{*}{ Solution A } & Sodium Nitrite & 0.5 & \multirow[t]{3}{*}{95} \\
\hline & Sodium Hydroxide & 0.6 & \\
\hline & Sodium Nitrate & 5.5 & \\
\hline \multirow[t]{3}{*}{ Solution A1 } & Sodium Nitrite & 0.3 & \multirow[t]{3}{*}{95} \\
\hline & Sodium Hydroxide & 0.3 & \\
\hline & Sodium Nitrate & 5.5 & \\
\hline \multirow[t]{3}{*}{ Solution B } & Sodium Nitrite & 0.5 & \multirow[t]{3}{*}{95} \\
\hline & Sodium Hydroxide & 0.6 & \\
\hline & Sodium Nitrate & 8.0 & \\
\hline \multirow[t]{3}{*}{ Solution C } & Sodium Nitrite & 0.5 & \multirow[t]{3}{*}{95} \\
\hline & Sodium Hydroxide & 1.0 & \\
\hline & Sodium Nitrate & 8.0 & \\
\hline \multirow[t]{3}{*}{ Solution D } & Sodium Nitrite & 0.0 & \multirow[t]{3}{*}{95} \\
\hline & Sodium Hydroxide & 1.0 & \\
\hline & Sodium Nitrate & 8.0 & \\
\hline \multirow[t]{3}{*}{ Solution $\mathrm{E}$} & Sodium Nitrite & 0.0 & \multirow[t]{3}{*}{75} \\
\hline & Sodium Hydroxide & 1.5 & \\
\hline & Sodium Nitrate & 8.7 & \\
\hline \multirow[t]{3}{*}{ Solution F } & Sodium Nitrite & 0.5 & \multirow[t]{3}{*}{75} \\
\hline & Sodium Hydroxide & 0.6 & \\
\hline & Sodium Nitrate & 8.7 & \\
\hline \multirow[t]{3}{*}{ Solution $\mathrm{H}$} & Sodium Nitrite & 0.0 & \multirow[t]{3}{*}{95} \\
\hline & Sodium Hydroxide & 1.0 & \\
\hline & Sodium Nitrate & 9.7 & \\
\hline
\end{tabular}

1. These components were added to all simulated wastes: $0.1 \mathrm{M}$ sodium carbonate, $0.1 \mathrm{M}$ sodium sulfate, 0.05 sodium chloride, 0.05 sodium hypophosphate, and 0.005 sodium chromate. 
Table 3. Average Potentials From PPT Tests

\begin{tabular}{|c|c|c|c|c|c|c|c|c|}
\hline \multirow[b]{2}{*}{ Solution } & \multirow[b]{2}{*}{ Material } & \multicolumn{2}{|c|}{$\begin{array}{l}\text { Steady State } \\
\text { Potential (V) }\end{array}$} & \multicolumn{2}{|c|}{$\begin{array}{c}\text { Corrosion } \\
\text { Potential (V) }\end{array}$} & \multicolumn{2}{|c|}{$\begin{array}{c}\text { Specific } \\
\text { Potential (V) }\end{array}$} & \multirow{2}{*}{$\begin{array}{c}\text { Transition } \\
\text { Potential } \\
\text { (V) }\end{array}$} \\
\hline & & Fast & Slow & Fast & Slow & Peak & Step & \\
\hline \multirow[t]{2}{*}{ A } & A537 & -0.309 & -0.239 & -0.460 & -0.228 & 0.000 & & -0.323 \\
\hline & A285 & -0.351 & -0.284 & -0.485 & -0.349 & 0.000 & & -0.447 \\
\hline \multirow[t]{2}{*}{$\mathrm{A} 1$} & A537 & -0.218 & -0.174 & -0.355 & -0.177 & & 0.100 & -0.177 \\
\hline & $\mathrm{A} 285^{*}$ & -0.281 & -0.282 & -0.660 & -0.386 & & $0.1-0.2$ & -0.386 \\
\hline \multirow[t]{2}{*}{ B } & A537 & -0.290 & -0.275 & -0.396 & -0.315 & & & -0.293 \\
\hline & A285 & -0.286 & -0.287 & -0.445 & -0.373 & & & $-0.373^{*}$ \\
\hline \multirow[t]{2}{*}{ C } & A537 & -0.287 & -0.285 & -0.384 & -0.274 & 0.000 & & -0.274 \\
\hline & A285 & -0.459 & -0.397 & -0.557 & -0.412 & 0.000 & & -0.412 \\
\hline \multirow[t]{2}{*}{ D } & A537 & -0.286 & -0.320 & -0.384 & -0.282 & 0.000 & & -0.282 \\
\hline & A285 & -0.342 & -0.313 & -0.443 & -0.321 & & & -0.321 \\
\hline \multirow[t]{2}{*}{$E$} & A537 & -0.293 & -0.306 & -0.565 & -0.399 & & $0.15-0.31$ & -0.399 \\
\hline & A285 & -0.307 & -0.291 & -0.557 & -0.374 & & 0.200 & -0.387 \\
\hline \multirow[t]{2}{*}{$F$} & A537 & -0.371 & -0.337 & -0.641 & -0.437 & & 0.200 & -0.437 \\
\hline & $\mathrm{A} 285^{\star}$ & -0.210 & -0.224 & -0.464 & -0.331 & & 0.200 & -0.331 \\
\hline \multirow[t]{2}{*}{ H } & $\mathrm{A} 537^{\star}$ & -0.329 & -0.375 & -0.610 & -0.496 & & ** & -0.496 \\
\hline & $A 285^{*}$ & -0.249 & -0.160 & -0.500 & -0.210 & & $* *$ & -0.210 \\
\hline
\end{tabular}

*Single result

** Over a large range of potentials 


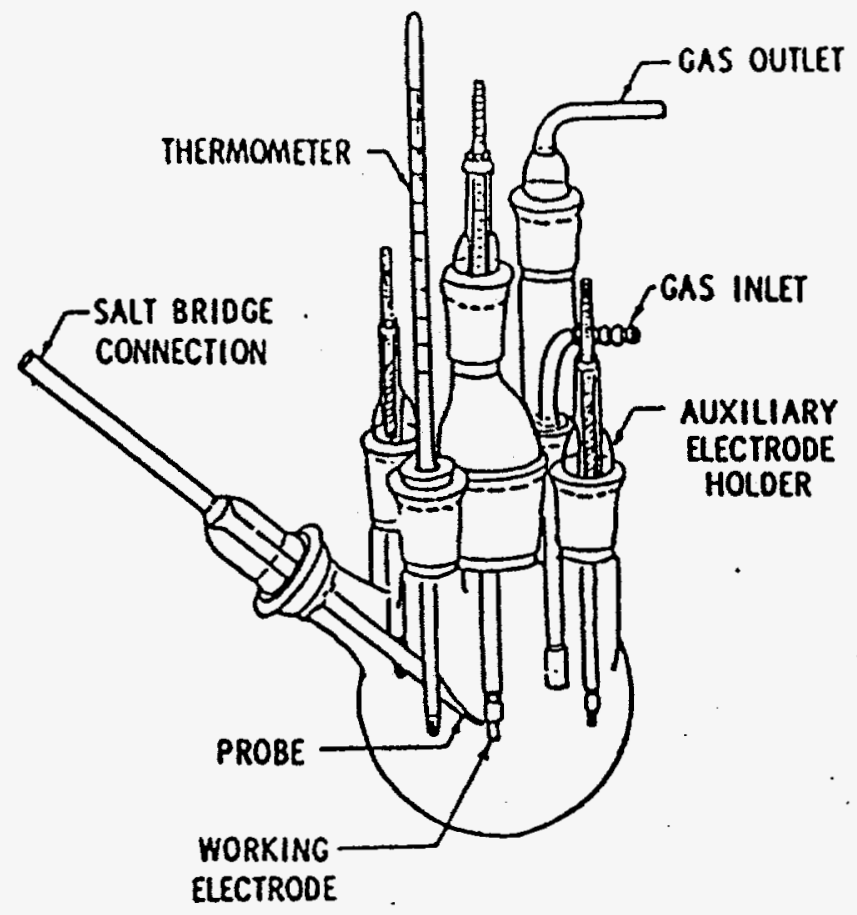

Figure 1. Schematic Diagram Of Polarization Test Cell (5) 


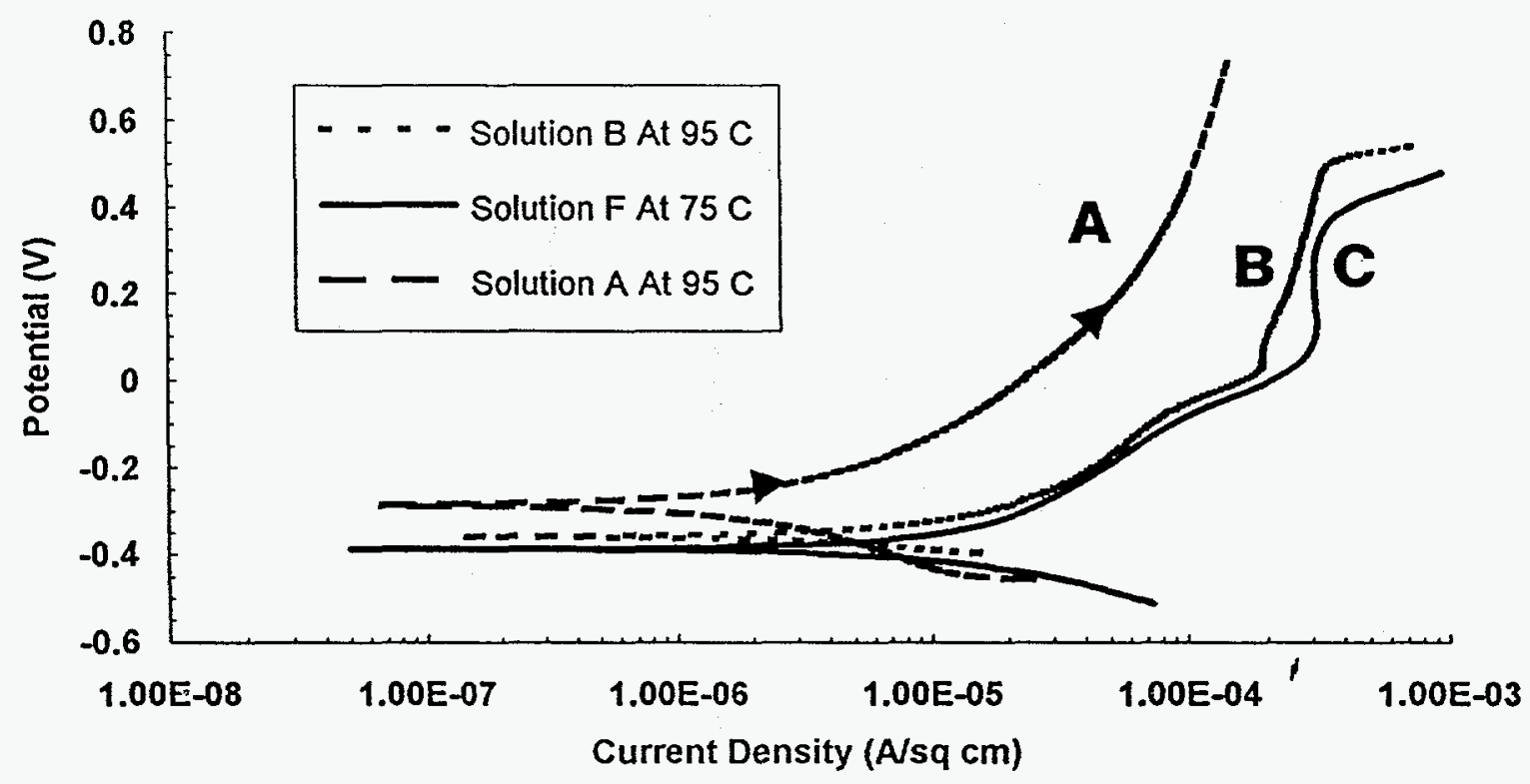

Figure 2. Potentiodynamic Polarization Test Results For Simulated Waste Compositions 


\section{DISTRIBUTION:}

D. R. Buchanan, 704-6C

B. L. Lewis, 703-8C

W. R. Parish, 703-8C

T. B. Caldwell, 703-9C

M. P. Reimnitz, 703-6C

R. G. Croley, 241-120H

T. J. Monahon, 703-H

J. E. Marra, 703-H

H. A. Abodishish, 703-H

T. C. Hsu, 703-H

M. C. Chandler, 703-H

G. K. Georgeton, 703-H

W. Van Pelt, 241-152H

W. L. Tamosaitis, 773-A

S. D. Fink, 773-A

D. T. Hobbs, 773-A

T. L. Capeletti, $773-41 \mathrm{~A}$

N. C. Iyer, 773-A

G. T. Chandler, 773-A

B. J. Wiersma, 773-A

P. E. Zapp, 773-A

MTS Files, c/o J. Gantz, 773-A, D1155 